\title{
Implementing Tolerance towards Minority Groups in an English Lesson Plan: A Proposal for People with Down Syndrome
}

Conchi Hernández Guerraa

\begin{abstract}
Even though tolerance towards minority groups seems a truism, students at early ages need to be educated on this issue. Minorities include categories such as race, religion, sexuality, cognitive disability, autism, physical impairment, among others. The aim of this paper is to present different English lesson plans prepared by students in which the inclusion of people with Down Syndrome is stated. Broad efforts have been made on an institutional level, but this study presents a more pointed focus. This proposal integrates the topic into the syllabus of an English class because this subject provides an invaluable opportunity to put social matters into practice. To this end, an example of an English lesson plan prepared by future English teachers is offered in which respect, tolerance, and acceptance towards people with Down Syndrome is implemented. Results show that values flow naturally while teaching a subject and that creativity is an asset in this work.
\end{abstract}

Keywords: English; inclusion; lesson plan; minorities; tolerance.

Recibido: 17 febrero 2019 - Evaluado: 28 mayo 2019 - Aceptado: 3 julio 2019 


\title{
Fomento de la tolerancia hacia las minorías en una unidad didáctica de inglés: una propuesta para las personas con síndrome de Down
}

Resumen: Aunque la tolerancia hacia los grupos minoritarios parece obvia, los estudiantes en edades tempranas necesitan educarse sobre el tema. Las minorías abarcan categorías como raza, religión, sexualidad, discapacidad cognitiva, autismo, discapacidad física, entre otras. Se han realizado grandes esfuerzos a nivel institucional, pero este estudio presenta un enfoque más intencionado. Por esta razón, el objetivo de este trabajo es presentar diferentes unidades didácticas que elaboraron futuros docentes de inglés en los que se promueve el respeto, la tolerancia y la aceptación hacia las personas con síndrome de Down. Esta propuesta integra el tema en el programa de estudios de una clase de inglés dado que brinda una oportunidad invaluable para poner en práctica los asuntos sociales. Los resultados muestran que los valores fluyen con naturalidad cuando se enseña una asignatura y que la creatividad es un activo en esta labor.

Palabras clave: inglés; inclusión; unidad didáctica; minorías; tolerancia.

\section{Fomento da tolerância às minorias em um plano de aula de inglês: uma proposta para as pessoas com sindrome de Down}

\begin{abstract}
Resumo: Embora a tolerância aos grupos minoritários pareça óbvia, os estudantes precisam ser educados sobre o tema. As minorias abrangem categorias como raça, religião, sexualidade, deficiência cognitiva, autismo, deficiência física entre outras. Grandes esforços têm sido realizados em nível institucional, mas este estudo apresenta uma abordagem mais intencionada. Por essa razão, o objetivo deste trabalho é apresentar diferentes planos de aula que futuros docentes de inglês elaboraram, nos quais o respeito, a tolerância e a aceitação das pessoas com síndrome de Dow são promovidos. Esta proposta integra o tema no programa de estudos de uma aula de inglês, tendo em vista que oferece uma oportunidade valiosa para colocar em prática os assuntos sociais. Os resultados mostram que os valores fluem com naturalidade quando uma disciplina é ensinada e que a criatividade é um ativo nesse trabalho.
\end{abstract}

Palavras-chave: inglês; inclusão; plano de aula; minorias; tolerância. 


\section{Introduction}

There is no internationally agreed definition as to which groups constitute minorities. The United Nations Humans Rights, for example, refers to minorities based on those national or ethnic, cultural, religious, and linguistic identity (United Nations Human Rights, n.d.). Marger (1994), on the other hand, considers minority groups to be those with less political, social, and economic power relative to the dominant group (p. 44). With respect to North America, minority groups mean mainly ethnic groups such as African Americans, Native Americans, Asian Americans, Jewish Americans, Hispanic Americans, and women (Moore, 2006, p. 35) These groupings mostly focus on skin color, rather than other differentiating categories, but a sense of "less social power" is implicit. Other key concepts to the term is that the group must be numerically inferior to the rest of the population and in a non-dominant position. Williams and Reisberg (2003) use the term "exceptional students" to refer to students with emotional and behavioral disorders and learning disabilities in the areas of organization, self-management, social skills, and learning strategies. The concept of differential treatment is common to all these minority group characterizations. Differential treatment leads to another concept: stereotypes.

Moore (2006) considers that:

stereotypes-the tendency to categorize individuals or groups according to an oversimplified standardized image and attribute certain characteristics to all members of the group-are central to the formation of prejudice and the pervasive acts of violence, segregation, and discrimination directed against minority groups (p. 36)

Indeed, negative stereotypes are the origin of negative attitudes towards different minorities. The presumption that all minorities engage in bad behavior or are less or more dangerous than other groups creates irrational and unjustified feelings of hate and discrimination.

This prejudice is primarily associated with racial discrimination, but other types of discrimination, such as genre, religion, physical handicap and disability, are also the subject of reflection in a society that wants to promote tolerance and equality of opportunity. The role of the teacher here is crucial, and the way of dealing with this topic is the aim of this paper. Moore (2006) states that "researchers found that education, while far from a panacea for America's racial woes, can be effective in reducing prejudice and discrimination if teachers challenge entrenched stereotypes and emphasize the importance of expanding equal educational opportunities to all students" (p. 37).

Finally, problems in youth like mobbing, sexual harassment, and toxic relations are growing inexplicable and staff in schools are aware of them. Related to this, the recent debate in Spain about whether schools with special needs should disappear in order to promote inclusive education has led to the discussion of whether society is thoroughly prepared for it.

\section{Literature}

Some studies have been done about teachers' opinions of inclusion. To understand their perspective towards students with special needs, two terms must be taken into consideration: "inclusion" and "attitude." Inclusion is conceptualized as being part of the concept of diversity and fosters participation (Sansour \& Bernhard, 2018, p. 127). The final aim is to promote normalization, which means finding a way to ensure that conditions for children with special needs are similar to those for normal children. Ghergut (2001) outlines three types of normalization: functional normalization (ensuring specific conditions to persons with deficiencies), social normalization (membership in a small group), and social reconstruction (extending social group towards public life). Verza (1998) defines school integration as the adjustment of a child to the requirements of the school that he or she attends. School integration, according to Ghergut (2001), involves the inclusion of special-needs students alongside other children in learning skills and school participation, commensurate with their potential. Ghergut (2006) also presents an interesting approach to the concept of integration by detailing what it is not. Integration does not mean the isolation of children with special needs in special classes within the school, or isolating 
them from the rest of the class by not involving them in learning activities. Integration does not mean accepting children with special needs into specialized schools just for profit, without the necessary training and support.

Allport (1959) defines "attitude" as a subject's stance towards another subject, object, or situation. Larousse (1998) explains that the concept of attitude covers various meanings. There are personal attitudes of individuals and social attitudes of groups, both having in common a set of personal reactions towards a determined object: animal, person, idea, or thing. "Tolerance" is a term defined as "recognizing and respecting others' beliefs and practices without sharing in them" (Darrow 2017). Teachers' attitudes play a decisive role. Lupu (2017), for instance, surveyed teachers about their opinion of having students with disabilities in class. In the literature reviewed, she could see some secondary problems such as focusing too much on these students or on the lesson; children with physical impairment are more welcome than others with mental deficiencies; and primary teachers are more open to the idea than teachers from secondary schools, for instance (pp. 30-31). The study was conducted in Romania and results concluded that teachers are in complete agreement with integration. In this study we conclude that from a theoretical perspective they will not reject these students but from a practical perspective they do not believe much in the positive results.

With respect to this discussion so far, this topic has a reverse side of the coin. On some occasions, when we are dealing with ethnic diversity, it is the minority that does not want to integrate itself. For example, Grose (2010) explains how some Muslim minorities, mostly Uyghurs, resist integration with Han in Eastern China. While some integration programs have been carried out, in some circumstances it was noticed that Uyghurs students were reluctant to have contact with Han due to the language difference. The conclusion we can derive from this experience is that regardless of whether or not institutions try to make changes in the policies of integration of minorities, the attitude of citizens or society in general towards integration is also a factor.

The literature reviewed here makes reference to the integration of different students in the classroom, but little literature was found that discusses the topic of tolerance and acceptance of minorities in class syllabuses. There are some American magazines such as Teaching Tolerance, We Are Teachers and Edutopia, which make a good effort by providing materials to be worked on in class and questions to be asked that stir reflection on our opinions and attitudes towards those that are different. Teaching Tolerance, for instance, offers curriculums designed specifically to teach tolerance and acceptance of diversity (Southern Poverty Law Center, 2016).

UNESCO has also published a bulletin called Teaching Respect for All. This constitutes an ambitious project to "counter discrimination and violence through strengthening the foundations of mutual tolerance and cultivating respect for all people, regardless of color, gender, class, sexual orientation, national, ethnic or religious orientation/identity." (UNESCO, 2012, p. 6). The bulletin provides a series of wise comments and pieces of advice to be followed in class, regardless of the minority group members in the classroom. In 2002, UNESCO published Global Monitoring Reports. This publication states that "discrimination is complex, with ethnicity, religion, poverty, gender, disability, and sexuality being intertwined. Consequently, merely providing opportunities to attend school will not suffice to eliminate discrimination or to universalize participation." And finally, Perspectives for a Diverse America offers interesting resources with materials on this topic organized for different age levels. While the materials are good for generally working in classes, they are not focused on specific subjects.

There are some recently published studies that address the topic of tolerance with respect to particular class subjects. Darrow (2017), for instance, in her Teaching Tolerance in the Music Classroom, attempts to prevent discrimination and promote tolerance of all targeted groups, but particularly students with disabilities. She provides important facts about the state of the art and a serious 
reflection on the matter. Also, Levina et al. (2015), in Teaching Tolerance in the English Language Classroom, provide a series of exercises to be done in 80 minutes in which tolerance, beliefs and opinions are the core of the activity.

Apart from specific examples, the topics are mostly related to racial and religious minorities. The purpose of these papers is mostly to discuss the integration of these minorities into society, what measures have been carried out so far, etc., as activities conducted by institutions to develop measures to facilitate integration of different races or religions. In Europe and the United States, institutions have made great efforts over many decades to integrate minorities. Results vary, but the recognition of many different options is one of the aims. Still, there is scant literature on how to work with students and open their minds on tolerance and integration through class activities in different subjects, regardless of whether or not students within the class exhibit different capacities. Tolerance as examined in this paper covers any minority group, whether intellectual, physical or for personal choice.

Moore (2006) proposes a lesson plan that covers discrimination throughout American history. In a way, it is a revelation of the things that have been done wrong, for the purpose of not repeating them. The aim is not just to see it in class, but to put it to use by institutions and other organizations. In Moore's plan, students watch a video called The Shadow of Hate, a 40-minute documentary that deals with racism in America. The teacher then provides some questions about the topic and students end the lesson with a personal reflection.

Makharadze (2010), on the other hand, offers a way of facilitating social integration for adults with intellectual disabilities in Georgia, by considering experiences from Poland and the USA. Makharadze studies the need for inclusion of disabled people in the labor market and its implication for both institutions and families. Because the social pension they receive is below Georgia's minimum salary, their exclusion and seclusion created by institutions is not the best measure of whether their integration into society is equivalent to that of any other citizen.
The environment of this paper's focus, however, is the classroom. Related to academia, the term "inclusive education" is appropriate. It refers to teaching in classes that have impaired students. Legislation in many countries includes an "inclusive education" initiative, and results have been varied. Some papers have been published related to the role of teachers in these classes (Shaukat et al., 2013) and how motivation affects results. In this study, the attitudes of children without disabilities towards the disabled were more negative than the impairment itself.

There are some psychology journals that offer facts and propose some actions to be carried out, but none address the topic of this paper; that is, to talk about these topics in class, not in relationship to a minority group within the school, but to reinforce tolerance and respect when encountering difference in students' lives.

Williams and Reisberg (2003) agree that there is a need to include tolerance within the teaching of a specific subject:

Typically, social skills are presented as an "add on" where 20 minutes is carved out of the day 3 days per week and set aside for social skills instruction. This type of format is less effective in teaching and generalizing the skill in part because it decontextualizes it. Rather, integration of the skill into ongoing lesson plan delivery would be optimal. This can be accomplished through an integrated curriculum approach. (p. 207)

However, their studies are more focused on disruptive behavior. The group to which this paper is dedicated is people with Down Syndrome. They could be classified as disabled. Down Syndrome is a genetic condition with some physical traits like low muscle tone, short stature, an upward slant to eyes. It also entails some difficulties in the process of learning. Different terms have been offered as an alternative, to avoid the perception of treating people with Down Syndrome as inferior. In 2014, the British government published a guide about inclusive language that suggested words to use and words to avoid when writing about disability, recommending that, collectively, persons with Down Syndrome should be treated as persons "with a 
learning disability." Down Syndrome is a condition, not a disease. This fact underlies the preference to say, "child with Down Syndrome," rather than "Down's child." This concept supports recognizing the person before recognizing her or his condition. "When you see a person with a condition, rather than defining that person by that condition, you first notice that this is a fellow human being who happens to have a particular condition" (The Chartered Insurance Institute, 2018). This very same idea was expressed by former president Barack Obama when referring to Nick, a person with Down Syndrome:

But I want everybody to hear Nick's wisdom here. He said, "What you call people is how you treat them. If we change the words, maybe it will be the start of a new attitude towards people with disabilities.' That's a lot of wisdom from Nick (Obama, 2010).

It is important to note that a learning disability is distinguishable from an intellectual disability. In the first group, hyperactivity and other signs are included, while intellectual disability includes people with remarkable limitations in learning, thinking, solving problems, and lacking the ability to live on their own. Here, again, we see the importance of terminology. Intellectual disability is distinguished from mental illness and a learning disability is a subset of intellectual disability.

Another term used in this context is "impairment." Disabilities include physical and mental impairments, which can involve cognition and learning. This includes dyslexia, attention deficit hyperactivity disorder, brain injury, genetic disability, among others. People with Down Syndrome fall within the genetic disability group.

In summary, understanding pertinent terms and the medical implications of each will help us normalize the condition as a specific human characteristic, and enable the understanding that the condition will dictate the appropriateness of the performance of some activities, but not others.

\section{Aim}

The aim of this paper is to present a proposal related to this topic based on the lesson plans prepared by fourth-year students pursuing a degree in
Modern Languages at the University of Las Palmas de Gran Canaria, Spain to show a different way to implement topics like inclusion in curricula. Teachers' and educators' responsibility for teaching values and not only a subject is here shown. Students were asked to form groups and the only instructions given were first to implement respect for the Down Syndrome collective permeated in an English lesson plan and, secondly, to be as original as possible. To do this, they could use all the resources they considered appropriate.

One of the compulsory subjects participants study is "Didactics of the English Language and Methodology for an Education for Integration and Equality," the purpose of which is not only to learn how to teach but, most importantly, how to prepare lesson plans that incorporate the concepts of integration and equality as controversial and important aspects in our society.

Most of these students will be future English teachers, and one of our aims has been to make them aware of the powerful tool they have as such. Through the teaching of different skills, they have the opportunity to work with current and important topics and make students reflect on the need to build a better world. Most of them will be teachers in secondary school, instructing teenagers between 12 and 17 years old. This is a complicated age range, during which confusion and frustrations arise and are handled with aggressiveness and rage, among other emotions. Behaving with tolerance, respect, and politeness cannot be taken for granted.

On the other hand, these future teachers have the advantage of being young and, consequently, innovative and original. They understand the mentality of teenagers and how to reach them much better than senior teachers, so new and fresh ideas may arise and it should be the aim of the teacher to provide the atmosphere and environment to let them flow.

\section{Materials and Methods}

The activity was conducted with fourth-year students of the Modern Languages program with the objective of implementing a video related to 
integrating youngsters with Down Syndrome to a lesson plan. This lesson plan was prepared for teenage students at a high school with B1 level and no further instructions were offered. The video is called "How do you see me?", in which a famous actress, Olivia Wilde, is seen doing everyday activities like watching TV with a friend, dancing, singing, practicing sports, or reading a book. At the end of the video, her image is displayed in a mirror and the camera turns it to a girl with Down Syndrome. The purpose of the video is to show how persons with trisomy can live a life similar to ordinary people. Using this material, students have to create a two-hour lesson plan that incorporates different skills, finishing with a wrap-up activity related to the video. The most original results were presented.

The work was conducted in four-person groups, with members randomly assigned by the teacher. A four-hour class was offered to help them decide how to organize the lesson plans, develop and find the materials, and deliver a presentation. Given that this study took place during the semester in which these participants were also performing their labor training and submitting final papers, they fell short of time to do some tasks. Thus, they agreed that four hours was enough time to build up the lesson plan, activities, and presentation in groups. Students in need of extra time to perform the assigned task completed it by themselves. They were to present the lesson plan and provide the necessary exercises in every skill worked. The video had to be smoothly implemented, and the lesson had to end with some wrap-up activity with tolerance as its aim.

Once the students had been given the instructions, they were free to ask whatever questions they had about the work, and the teacher was able to monitor task progress. Upon arrival of the completion deadline, every group orally presented their work, explaining in their own words how and why they chose their activities. In this way, every group benefited from the different ideas of their classmates for use in future exercises. All of them had agreed to share the information.

\section{Results}

In total, 15 groups made presentations. They devoted four hours to the preparation of the lesson plan and every group had to explain it in fifteen minutes as a maximum. They were said that originality and attractiveness of exercises would be much appreciated. Groups were formed by four to five people and everyone had a role in the preparation and delivery. The presentation was addressed to fictitious colleagues in a seminar-like mode so the style of the speech had to be academic.

The different exercises they chose for each section of the presentation will be explained and summarized in the table below. First, we examine the titles they offered for their work. These include: "Yes, We Can"; "I Don't Put Dis- in my Abilities"; "May You Be an Ambitious Person?"; "More Alike than Different"; "A Place for Everyone"; "How Do You See Me?"; and “Judging by Appearances." As we can see, self-esteem was also encouraged.

\section{Activity 1. Warm-up}

There were primarily two methods utilized here. Some decided to start the class with the viewing of the video, followed by questions about it. In one case, the group played the video, but without the final scene where the condition of the girl in the video is revealed. After viewing every section, some questions were asked, such as: "What do you think?" "Do you identify with her?" "Do you have something in common?" "How do you see the girl? The same way she sees herself?" "How do you think the video will end?" and so on. After returning to show the final portion of the video, questions included: "Did you expect that ending?" "Is it surprising?" "Why?" "Why not?"

The majority of students, however, preferred to start differently. Some started with few pictures of celebrities. It was explained who the celebrities are and why they are famous. Then, the celebrities' handicaps were revealed. Another group displayed pictures of people with different personalities: shy, angry, etc. 
Another plan involved an activity in which a student left the room and the rest of the group described that person. They took notes of all the ideas they described. Then, the student returned and explained to the class how he or she saw himor herself. Then they contrasted the opinions.

\section{Activity 2. Vocabulary}

Activity 2, related to vocabulary, was dedicated to personal feelings. This follows the video in which we see the character in different situations displaying different moods. The vocabulary exercise was divided into two parts: matching, in which emojis have to be matched with the term they represent; and fill-in-the-blank sentences, using the words provided by the matching part.

Students also favored exercises about "opposites." The words selected could not be very basic and had to relate to feelings and emotions. For example, a big group was called "happy" and synonyms related to the feeling "happy" were supplied. The same exercise can be conducted with antonyms.

\section{Activity 3. Grammar}

In Activity 3, related to grammar, most groups opted for explaining the different future tenses. According to the level, they focused on a different one; and after that, exercises related to the use were offered. Some groups preferred to work with modal verbs of probability, where, based on participants' expectations of a future "happening," they constructed sentences. These were then contrasted with real, remarkable characters that have overcome lots of difficulties. The same exercise can be applied to a list of phrasal verbs capturing daily, routine actions. First, students match the phrasal verbs with definitions and build up sentences using them. They can explain their personal experience with these actions: how often they do them, at what time of the day, and so on. Secondly, the teacher can ask whether there are people who cannot do these actions, and whether they need help doing them, or not. Others preferred to work with wishes and regrets, and the sentence structure "I wish I..."; using simple past- and past-perfect tenses is another option. It can be used as an encouragement tool for students.

\section{Activity 4. Reading}

Activity 4 involved reading. While there were different opinions, most agreed on reading a text related to Down Syndrome. The story could commemorate its World Day or provide a specific example of the daily life of a person with this trisomy. The text would be adapted, and some comprehension questions would be provided.

Another exercise involved reading a text where students underlined all the vocabulary related to physical description and personality. Then they listened to and wrote down vocabulary related to mental and physical diseases. This exercise ended with a roleplay in which one person simulated having an illness and another asked about his or her daily life.

Another creative, different exercise required that students figure out the ending of a story. They were asked to think of what students can do to prevent the bullying of a friend. The teacher gave students the beginning of a story, taken from a website (https://freestoriesforkids.com/), and they had to finish it. The story began as follows:

\footnotetext{
Reggie couldn't hear a thing. He was a normal boy, but he had been born deaf. He was well known to everyone in town, and they were all very fond of him. Unfortunately, he always seemed to end up being treated differently from everyone else. Children worried that they would hurt him, that maybe he wouldn't hear the ball being hit in his direction. Adults acted like he was incapable of understanding them, as though he was a baby.

Reggie didn't like this very much. But the person who disliked it the most was his friend Michael, who decided one day that things had to change.
}

Another option could be a whole text like this, which was adapted from Community Tool Box: 


\section{Reading and exercises}

\section{Barriers to Integrating People with Disabilities in Mainstream Society}

In the last decade, the authorities have taken considerable steps to help people with disabilities integrate into the community. They include improvements to building access such as providing more toilets for people with disabilities, designating more tables at food centers for people with disabilities, installation of lifts and tactile tiles at train stations, provision of more wheelchair-friendly buses and amenities, etc.

While things have improved, people with disabilities still face barriers and challenges when they are out and about.

\section{Physical barriers}

Physical barriers are the most obvious and apparent of barriers. Kerbs, stairs and other physical structures usually prevent people with disabilities from entering certain places.

High slopes as well as narrow and irregular walks are problems for wheelchair users, who also often find it challenging to get into lifts and trains. There are facilities such as tactile tiles and toilets built specially for people with disabilities but they are usually blocked, locked, or used by able-bodied people, so they represent some of the challenges that people with disabilities have to deal with every day.

Building designs and urban planning should be based on the concept of 'Universal Design,' which includes everyone in the society-from people with disabilities to children and the elderly. We have to remove barriers and to provide accessible and usable environments for all kinds of people.

\section{Mental barriers}

Mental barriers occur on both sides, with the general population thinking that people with disabilities are dependent and fragile and housebound, and people with disabilities themselves who think they cannot go outside. Such thoughts can impede people with disabilities from participating in regular activities.

\section{Social barriers}

Usually resulting from both mental and physical barriers, social barriers hold people with disabilities back from stepping out and being seen and involved in activities in the community. Because of this fear, others may think that we do not need to include people with disabilities. Then, a vicious cycle is formed.

We need to remove the barriers preventing people with disabilities from participating in all areas in the community. Like anyone else, they should have the freedom to participate in every facet of life.

Public education is important. And encouraging an attitude that recognizes the value and worth of each individual, regardless of abilities, and recognizing their rights and dignity as members of the community will result in an inclusive environment for people of varying abilities.

\section{Match the listed terms with the definitions}

tile, amenity, kerb, deal with sth., housebound, able-bodied

1. 1. Unable to leave your house, especially because you are ill.

2. 2. Something that is intended to make life more pleasant or comfortable for people.

3. 3. The edge of a raised path nearest the road.

4. 4. Used to refer to someone who is healthy and has no illness, injury, or condition that makes it difficult to do things.

5. 5. A thin, usually square or rectangular piece of plastic used for covering floors.

6. 6. To take action in order to achieve something or in order to solve a problem.

\section{Write four sentences of your own, using four different terms from the previous exercise.}

You should try to use the future progressive tense.

Example: By 2020, all cities will have dealt with all the social integration problems. 


\section{Activity 5. Speaking}

This last activity was devoted to some speaking about the topic. Students should use the vocabulary provided and, if possible, the structures seen in class. Some questions were initially asked to open the debate, such as:

- How would you create a better society for people with disabilities?

- Have you seen places that need urgent improvements?

- Have you seen well-adapted places for the disabled?

Another exercise could be a student impersonating a famous character with a disability. He or she would answer the questions that classmates asked as they guess the character. They will realize that the character's life is as ordinary as any life without disability.

\section{Activity 6: Listening}

Lastly, students could listen to songs related to discrimination, such as "Where Is the Love" by The Black Eyed Peas, "Beautiful" by Christina Aguilera, or "Hall of Fame" by will.i.am, and fill in the lyrics.

\section{Discussion}

Youngsters with Down Syndrome are people with a role in society. There are many well-known examples of persons with Down Syndrome who are completely integrated into society. To name just a few, the Spanish Pablo Pineda got a university degree and is an awarded actor; Judith Scott is an outsider sculptor; and Madeleine Stuart is a model. Institutions and schools also play a developed role in the promotion and integration of persons with Down Syndrome in society and schools. But in spite of all this, there is still a long way to go until the normalization of this minority is complete. Prejudices still exist in many families.

This paper seeks to present a way to fulfill this normalization objective through increasing awareness of this reality in young students at high schools. Through any of the topics taught in an English class a social situation can be explained. In the exercise done with university students and future English teachers, the enthusiasm and originality of the works presented was overwhelming. They have the ideas; it is up to us to provide the tools for their development.

A secondary aim of these lesson plans is to improve self-esteem among the youth. It is not a surprise that teenagers live complicated lives filled with doubts, inferiority complexes, and problems with adults. Through these exercises, they may gain recognition of tolerance for uniqueness and differences, whatever they may be.

Table 1 offers a sample model of the activities previously described:

Table 1. Summary of activities of the lesson plan proposed

\begin{tabular}{|c|c|c|}
\hline Sections & Description & Examples \\
\hline Title & $\begin{array}{l}\text { The title may provide some clues as to the purpose } \\
\text { of the current class, not pointedly English, but rather } \\
\text { abstract concepts such as tolerance or individuality, } \\
\text { or the development of a sense of self }\end{array}$ & $\begin{array}{l}\text { - "Yes, We Can" } \\
\text { - I Don't Put Dis- in my Abilities" } \\
\text { - "May You Be an Ambitious Person?" } \\
\text { - "More Alike than Different" } \\
\text { - "A Place for Everyone" } \\
\text { - "How Do You See Me?" } \\
\text { - "Judging by Appearances" }\end{array}$ \\
\hline
\end{tabular}




\begin{tabular}{|c|c|c|}
\hline Sections & Description & Examples \\
\hline \multirow{3}{*}{$\begin{array}{l}\text { Activity } 1 . \\
\text { Warm-up }\end{array}$} & Some questions & $\begin{array}{l}\text { - "What do you think of this video?" } \\
\text { - "Do you identify with the girl?" } \\
\text { - "Do you have something in common?" } \\
\text { - "How do you see the girl? The same way that she sees } \\
\text { herself?" } \\
\text { - "How do you think the video will end up?" }\end{array}$ \\
\hline & Pictures of celebrities & $\begin{array}{l}\text { Step 1: } \\
\text { - Who are they? } \\
\text { - Why are they famous? } \\
\text { Step 2: } \\
\text { - Diseases are revealed } \\
\text { Step 3: } \\
\text { - Exercise with different personalities and moods }\end{array}$ \\
\hline & A student leaves the room & $\begin{array}{l}\text { Step 1: } \\
\text { - Students' descriptions of him/ herself (at the same } \\
\text { time) } \\
\text { - His/ her own vision } \\
\text { Step 2: } \\
\text { - Contrast of both opinions }\end{array}$ \\
\hline $\begin{array}{l}\text { Activity } 2 . \\
\text { Vocabulary }\end{array}$ & Matching feelings and emotions & $\begin{array}{l}\text { - Emojis } \\
\text { - Sentences to fill in } \\
\text { - Opposites }\end{array}$ \\
\hline $\begin{array}{l}\text { Activity } 3 . \\
\text { Grammar }\end{array}$ & $\begin{array}{l}\text { Future tenses } \\
\text { Modal verbs of probability } \\
\text { Phrasal verbs of daily routines } \\
\text { Wishes and regrets }\end{array}$ & $\begin{array}{l}\text { - Characters that have overcome big difficulties } \\
\text { - Matching up definitions and examples + personal } \\
\text { experience: Can everybody do these actions? }\end{array}$ \\
\hline $\begin{array}{c}\text { Activity } 4 . \\
\text { Reading }\end{array}$ & $\begin{array}{l}\text { Text related to Down Syndrome } \\
\text { General text } \\
\text { Reading a story }\end{array}$ & $\begin{array}{l}\text { - Comprehension questions } \\
\text { - Underline vocabulary related to physical description } \\
\text { and personality } \\
\text { - Mental and physical diseases } \\
\text { - Roleplay simulating an illness } \\
\text { - Write an ending }\end{array}$ \\
\hline $\begin{array}{l}\text { Activity } 5 . \\
\text { Speaking }\end{array}$ & $\begin{array}{l}\text { How would you create a better society for people } \\
\text { with disabilities? } \\
\text { Have you seen places that need urgent } \\
\text { improvements? } \\
\text { Have you seen places well adapted for the disabled? } \\
\text { Guessing characters }\end{array}$ & $\begin{array}{l}\text { - Debate with some previous preparation } \\
\text { - Well-known characters with a disability. Students do } \\
\text { some research about them. }\end{array}$ \\
\hline $\begin{array}{l}\text { Activity 6: } \\
\text { Listening }\end{array}$ & $\begin{array}{l}\text { "Where Is the Love?" by the Black-Eyed Peas } \\
\text { "Beautiful" by Christina Aguilera } \\
\text { "Hall of Fame" by will.i.am }\end{array}$ & - Fill in the gaps \\
\hline
\end{tabular}




\section{Conclusion}

Updating lesson plans to accommodate senior students that will one day become English teachers is an exercise that will not be wasted. Allowing them to be free in the preparation of materials, where the only requisite is to be original, opens a door to interesting, useful, and beneficial works. Indeed, the benefits are twofold: this material can be put into practice during their working hours in the semester, which provides personal satisfaction to them; and, secondly, they will be aware of the wide scope of possibilities they own in their classes, not to mention the social responsibility they have, too.

Added to this, a project has been launched with the main aim of this paper as starting point. Indeed, this has been the inspiration for a wider task in which students from several programs are involved; in this case, the different problems or addictions that young people can face, such as addiction to sports bets, alcohol or drugs, toxic relationships, bullying, addiction to social media, and so on. The first step of this project starts with Health students that give their vision of the reasons for these addictions or problems. This must be useful information for the next team, English students that will be future teachers. With this information they will organize a lesson plan to prevent these situations. The result will be sent to Social Work students that will organize a therapy. Then, Translation and Creative Stories students will do a final work with all the information gathered.

Involving students in a project where the work done will be useful for other collectives will act as a stimulating incentive and prepare them to work with other specialists in the future.

\section{References}

Allport, G. W. (1959). Attitudes. In G. Lindzey (Ed.), Handbook of Social Psychology (pp. 798-894). Boston: Addison-Wesley Publishing Co.

Darrow, A.A. (2017). Teaching Tolerance in the Music Classroom. General Music Today 30(3), 18-21.

Ghergut, A. (2001). Psihopedagogia persoanelor cu cerințe speciale. Strategiide educație integrată [Pedagogy of persons with special needs. Strategies for integrated education]. Iași: Polirom.
Ghergut, A. (2006). Psihopedagogia persoanelor cu cerinţe educative speciale. Strategii diferenţiate şi inclusive în educaţie [Pedagogy of persons with special education needs. Differentiated and inclusive strategy in education]. Iaşi: Polirom.

Grose, T. A. (2010). The Xinjiang Class: Education, Integration, and the Uyghurs. Journal of Muslim Minority Affairs, 30(1), 97-109.

Larousse (1998). Dicționar de psihologie [Dictionary of Psychology]. București: Univers Enciclopedic.

Levina, L., Lukamonva, O., Romanovskaya, L., \& Shutova, T. (2016). Teaching Tolerance in the English Language Classroom. Procedia - Social and Behavioral Sciences, 236, 277-82.

Lupu, N. (2017). Teachers Opinions towards the Integration of Students with Special Needs in Mass Education. Transilvania University of Brasov, Series VII: Social Sciences and Law, 10(1), 29-36.

Makharadze, T. (2010). Social Integration of Adults with Intellectual Disabilities in Georgia: Lessons from Poland and the USA. International Social Work, 53(1), 47-59.

Marger, M. (1994). Race and Ethnic Relations. Belmont, CA: Wadsworth.

Moore, J. (2006). Shattering Stereotypes: A Lesson Plan for Improving Student Attitudes and Behavior toward Minority Groups. The Social Studies, 97(1), 35-39. DOI: 10.3200/TSSS.97.1.35-39.

Obama, B. (2010). Remarks by the President at the signing of the 21st Communication and Video Accessibility Act of 2010. Obama White House Archives. Retrieved from: https://obamawhitehouse.archives.gov/ the-press-office/2010/10/08/remarks-president-signing-21st-century-communications-and-video-accessib

Sansour, T. \& Bernhard, D. (2018). Special Needs Education and Inclusion in Germany and Sweden. Alter, 12(3), 127-139.

Shaukat, S., \& Iqbal, H. M. (2013). Prospective Teachers' Locus of Control, Persistent Behaviour, Classroom Anxiety and Professional Mastery Beliefs. Pakistan Journal of Psychology, 44(2), 35-52. Retrieved from https://search.ebscohost.com/login.aspx?direct=true $\& \mathrm{db}=\mathrm{a} 9 \mathrm{~h} \& \mathrm{AN}=97396795 \&$ lang=es\&site $=$ eds-live\&scope $=$ site

Southern Poverty Law Center (2016). Teaching tolerance. Retrieved 2020, Feb. 06 from https://www.splcenter. org/

The Chartered Insurance Institute (2018). Inclusive Language Guidelines. Retrieved 2020, Feb 06 from https:// 
www.cii.co.uk/media/10120292/inclusive-language-guidelines.pdf

Unesco (2012). Teaching Respect for All. Retrieved 2020, Feb. 06 from https://es.unesco.org/

United Nations Humans Rights (n.d.) Minorities under International Law. Retrieved 2019, Mar 21 from https:// www.ohchr.org/en/issues/minorities/pages/internationallaw.aspx

Verza, E. (1998). Bazele psihologice ale educației integrate [Psychological foundation of integrated education]. In
E. Verza \& E. Păun (Eds.), Educaţia integrată a copiilor $c u$ handicap [Integrated education of children with disabilities] (pp. 29-35). Bucureşti: Asociaţia Reninco România.

Williams, G. J. \& Reisberg, L. (2003). Successful Inclusion: Teaching Social Skills through Curriculum Integration. Intervention in School and Clinic, 38(4), 205-10.

Zitrev, J. (2017, Sept. 19). How do you see me? Retrieved from https://www.youtube.com/watch?v=OlUhpWMN9W4 
